\title{
Long-term clinical follow-up after operation for lung carcinoma
}

\author{
R. A B B E Y S M I T H \\ Thoracic Surgical Unit, King Edward VII Chest Hospital, Hertford Hill, near Warwick
}

From 1951 to July 1969 , 964 lung resections for primary lung carcinoma have personally been carried out. All except eight patients, whose follow-up has been continued by colleagues elsewhere, have been examined at intervals in the outpatient department and chest radiographs have been taken. No patient has been lost from follow-up. The results of this follow-up are presented. The quality of the patient's life after operation, the cause of death, the results, and the relationship of survival to extent of operation are discussed. Details of 151 patients surviving more than five years, and of 49 surviving more than 10 years, are given. Information on the aspects under consideration is believed to be as complete as possible. The cause of death is doubtful in only two patients.

Many analyses of results of surgery for lung carcinoma are available. These reports have provided invaluable information on the influence on survival of such factors as cell type, the effect of lymph node involvement, spread beyond the lung, and the type of operation. Recently Higgins, Lawton, Heilbrunn, and Keehn (1969) analysed 40 factors of possible prognostic significance in patients submitted to surgery. They found the age of the patient and the extent of disease as found in the specimen the only factors exerting a strong influence on the long-term prognosis.

Less is recorded concerning the quality of survival, the exact cause of death in a complete series of patients operated upon, and details of those surviving 10 or more years after operation. Our results will be presented in factual form. When an opinion is expressed, it is from the evidence provided by a scrutiny of our results. Freedom to express an opinion is desirable provided that this is based on an adequate experience. It could be argued as a matter of opinion, for instance, that in the past too much attention has been given to tumour characteristics and too little to the medium in which the tumour grows, that is, the patient. Discussion confined only to those aspects of the tumour-patient relationship which can be expressed as facts will do little to clarify the important factor of the patient's defence mechanisms, resistance or immunity to his tumour, whichever term is preferred to describe this intangible concept. That at any rate some tumours are not autonomous has recently been discussed by Wood- ruff (1969). This appears to provide an abstract explanation for some features of tumour be-o haviour in the later post-operative years.

In this review the patient's follow-up is divided into four time periods, the immediate post-opera- $\frac{0}{8}$ tive, 2 to 5 years after operation, 5 to 10 years, and the period after the tenth completed year.

Definition of certain terms used is necessary. The types of operation are as classified by Chamberlain, McNeill, Parnassa, and Edsall (1959) into. standard resection when only the lung is involved and only the lung removed, extended (ex. in Tables) resection where the lung and somex adjacent structure such as atrial wall or peri- $\frac{0}{3}$ cardium is removed to achieve total macroscopic removal, and non-curative (N/C in Tables) re윽 section when it has been impossible to achieve total macroscopic removal and a portion of tumour has remained within the chest cavity at the conclusion of operation. Autopsy has noE. always included examination of the brain of routine examination of the limb bones and residual hilar nodes in those dying in the post? operative period, nor has it included microscopies examination of macroscopically normal tissue Involvement of lymph nodes at the time of operac tion signifies that microscopic examination o nodes sent for section confirms the presence of tumour tissue. Involvement has never been assumed from the gross appearances at operation $\frac{}{D}$ The operation records are not sufficiently consist? ent to allow accurate grading of node involvemen $\$$ as suggested by Nohl (1960). It is not possible 
to offer an accurate figure of the operability rate, that is, the percentage of referred patients who are operated upon. The closer the liaison with a referring physician, the more likely he is to refer only patients whom he considers operable, and therefore the operability rate may rise as high as 8 out of 10 referred for possible surgery. The resectability rate- the percentage of patients operated upon who have the tumour resected-has remained high at about $95 \%$ throughout. An accurate figure relating the number of patients in a given population operated upon for lung carcinoma with the total number dying of lung carcinoma in the same population cannot be offered. A distinction is made between the survival rate after operation as a percentage of the total number of operations, of the total number of tumour's resected, and of the post-operative survivors.

\section{PATIENTS UNDER REVIEW ON CLOSING DATE OF} STUDY, 1 JULY 1969

Nine hundred and sixty-four patients had been operated upon and the tumour removed. Some of these patients had more than one operation. Before July 1959 (potential 10-year survivors), 302 resections were performed from 319 explorations, and between July 1959 and July 1964, 304 resections from 321 explorations. This adds to a total of 606 resections (potential five-year survivors) since the beginning of the study in 1951 .

Adaptation to post-resection life is used in the text and in Tables III and IV as a comprehensive term indicating the patient's general well-being, ability to work, absence of serious dyspnoea and pain, and return to his previous place in society. 'Good' adaptation is when this has been achieved, 'bad' when the patient has failed to do so without there being an obvious reason, and 'unsatisfactory' when such factors as increasing dyspnoea, mental breakdown, or other serious illness have prevented adaptation in spite of the patient's anxiety to adapt. We think an attempt to differentiate those unwilling from those unable to adapt should be made. Radiotherapy has not been used except as a palliative in terminal recurrent disease.

We do not propose to divide the total resections into lobectomy or pneumonectomy, but to detail only the long-term survivors. The same applies to such well-documented factors as age, sex, length of pre-operative history on postoperative survival. Our results based on these criteria do not differ broadly from those of other authors.

\section{IMMEDIATE POST-OPERATIVE PERIOD}

From 964 resections, 73 patients died in hospital, a hospital mortality of $7.5 \%$. Autopsy was carried out in 66 of these 73 hospital deaths. Only two points arising from these figures will be discussed -the incidence and distribution of metastases at the time of operation and the incidence of pulmonary embolism as a cause of death.

A high autopsy rate in the post-operative deaths was considered important in assessing the frequency of distant metastasis at the time of operation, and in deciding what methods could be used to detect metastasis before thoracotomy. Lymph node involvement of the local glands was not included as a distant metastasis. From 66 autopsies, 11 patients $(168 \%)$ were found to have distant metastases. Of four patients in whom the metastases were in the suprarenal, three had impalpable metastases in one suprarenal, and one had easily palpable metastases in both suprarenals. Three patients had palpable single metastases in the kidney, three patients had metastases in the liver, palpable in two patients, and one had an impalpable deposit in the fourth lumbar vertebra. Only one patient had tumour in more than a single organ, and in only one, the patient with bilateral adrenal metastases, did the metastases contribute to the post-operative death. In only three patients would laparotomy have confirmed the presence of distant metastases from a total of 66 patients examined at autopsy. Our objections to the possible advantages of pre-operative laparotomy arise from examination of the body after death. We have no first-hand experience of pre-thoracotomy abdominal exploration. The arguments in favour of this procedure have been clearly stated by Bell (1967).

Le Roux (1968) described the findings in 121 patients dying in hospital after pneumonectomy. In his study, glands beyond the area of clearance at pneumonectomy were found to be involved in 42 patients, and from the total of 121 patients only 21 were found not to have evidence of tu.nour spread. Ten patients were not autopsied. This high figure of spread detected at autopsy in patients dying after pneumonectomy is remarkable. In the absence of a positive statement from the author, no assumption can be made of possible spread in survivors, but neverthe ess this important observation raises a suspicion that extrapulmonary spread may not be unusual among survivors. We have observed 10-year survival in patients with extrapulmonary spread to glands and other sites at the time of operation. 
Pulmonary embolism was confirmed as the cause of death in 25 of the 66 patients in whom autopsy was carried out, and might have caused death in two other patients from the remaining seven on whom autopsy was not performed. There was no doubt from the autopsy findings that pulmonary embolism was the cause of death in each of these 25 patients. From a total of 66 this figure is inexplicably high. During the last 10 years it was the main single cause of death, in spite of steps to avoid this complication. The patient was, whenever possible, encouraged to be out of bed for a time after the first 24 hours. Cardiac arrhythmia was treated, but anticoagulants were never used. Every operation was performed with the patient in the prone position on the operating table. This was considered a possib'e contributory cause, although Belcher and Anderson (1965) reported only seven deaths due to pulmonary embolus from a total of 91 postoperative deaths, and mentioned the prone position as a possible explanation for their low incidence of embolism. Le Roux (1968) reported 34 deaths due to pulmonary embolism from a total of 156 post-operative deaths.

There were several interesting features about these embolic deaths. In all but three, the patient was out of bed, apparently well, when the embolus occurred, suggesting that early ambulation promoted the dislodgement of weakly adherent clot from the iliac or femoral veins. It would be interesting to know the effect on the embolus incidence of resting the patient in bed for a period of at least two weeks after operation. The results could not be less favourable than on our present regime for embolus prevention. No correlation between embolus and atrial fibrillation earlier in the post-operative period was noted, although fibrillation was common because of the large number of extended intrapericardial resections performed.

Another interesting feature was that pulmonary embolism, when it occurred, produced total circulatory collapse within some 15 minutes from the first complaint of pain, and was invariably fatal after either lobectomy or pneumonectomy. Only once was a less severe degree of symptoms from pulmonary embolus recognized in the entire series of 964 patients. This patient was at no time in severe collapse and recovered uneventfully. For some reason, in this series there was no observed pulmonary embolus other than dramatic in onset, characteristic in symptomatology and always fatal, with the single exception recorded. As a result, an attempt at removal of the embolus was made in the last two patients in whom this occurred, in circumstances which offered some $\stackrel{\overrightarrow{5}}{+}$ chance of survival in terms of immediately avail-o able facilities. In both patients the heart beat had stopped. In one the embolus was not detected by? the finger within the pulmonary artery. Subse 0 quently, at autopsy, an embolus within the pul monary artery was confirmed. The second patient did not survive. Little time is available to con-firm the diagnosis. During the same period the $\vec{w}$ only diagnosis likely to cause confusion, coronary? artery occlusion, was confirmed in only three patients at autopsy, although in another founi patients less severe degrees of collapse duringconvalescence were due to coronary occlusion. In our experience, circulatory collapse of abrupto onset is much more likely to be due to pulmonary. embolism than to any other cause, and, given favourable circumstances, is an indication for an immediate exploratory operation.

\section{PERIOD 2 TO 5 YEARS AFTER OPERATION}

In this period $90 \%$ of those patients who died, died with clear evidence of spread of carcinomas although the immediate cause of death was no: in every case related directly to this spread. The diagnosis of cerebral metastases was not always confirmed by autopsy. Three patients were oper ated upon for an isolated cerebral metastasis occurring before, but none after, the fifth post 5 operative year. No patient survived more than two years following the cerebral operation.

The most frequent symptom affecting the quality of the patient's life was chest pain, and itw might be appropriate to mention some aspects of this important symptom. The site of incision, the resection of a rib, the extent of chest wall resec. tion, and the fracture of a rib by the rib spreader did not appear to be related to the amount of pain suffered. A number of patients, after thoraco tomy through the bed of a resected rib with fractures of the rib above and below, suffered minimal pain. Pain subsided as a significant sympon tom by the fifth year, if a generalization can beu offered on a symptom of such uniqueness to tho patient. Provided a metastasis in the rib, vertebraf body or mediastinum was excluded, which was never easy, the origin of persistent pain wa: generally considered to be psychological and not to be treated by any physical means. Intercosta $\vec{L}$ nerve injections, for instance, appeared to fix ins the patient's mind that a cause for the pain existed. and from that point the patient expected a cure $\frac{\vec{D}}{\mathrm{D}}$ Our experience of providing this cure by physicaP means was limited, but we observed patients in 
whom, by a combination of persuasion and explanation, pain became of less consequence through each year of survival. This pragmatic approach to the problem of pain was generally successful. Other methods doubtless achieve the same end. Exceptions were the patient with metastases, not visible radiologically, and the patient whose personality was considered inadequate to the demands of post-resection existence. In the former category pain was established within 18 months of operation as a rule, although we observed pain due to bone metastasis occurring for the first time as long as 11 years after resection. Management was difficult because the cause was uncertain. As soon as bone erosion was detected radiologically, the lesion was treated by radiotherapy. Excluding three patients whose pain developed 6,10 , and 11 years after resection, and in whom clear radiological evidence of carcinoma existed, no patient had metastatic erosion of long bones, ribs or spine detected after the third year, or, in other words, erosion of ribs was associated with relatively early post-operative death. Our experience may be summarized by stating that, provided radiological changes were absent, chest pain persisting after the third post-operative year was not due to metastases.

The other category of persistent pain occurred in the patient of inadequate personality. We shall refer later to this in considering such associated features as failure to return to work or to accept post-resection existence. Pain forms an important part of a symptom complex in those whose quality of survival was disappointing although they survived 10 or more years.

An increased tendency to minor chest infection was a frequent symptom, but only where this materially affected the patient's existence will it be mentioned. Symptoms from reflux oesophagitis and of pains in the legs from intermittent claudication arose before the fifth year in those reporting such symptoms at follow-up. Both of these common symptoms seemed to arise more frequently after operation than in a similar age group of patients taken at random. These symptoms subsided on conservative management, and in no patient did serious sequelae develop. The improvement of the symptoms of intermittent claudication with age is hard to explain, but a number of patients had more severe symptoms at two years than at five years after operation.

Haematuria of sufficient persistence to require renal investigation occurred before the fifth year in three patients. Investigation demonstrated a kidney lesion. Nephrectomy was carried out be- cause of the possibility of a primary renal lesion. In each patient the kidney lesion was metastatic and death occurred within a year of nephrectomy.

Chronological details of the 606 patients resected more than five years previously have been given. These are from a total of 640 explorations. Of the 606 resections, $151(24.7 \%)$ lived more than five years. These patients, for the purposes of analysis, are subdivided into 64 patients alive between 5 and 10 years, 38 dead between 5 and 10 years (Tables I, IIA, and IIB), 38 patients living more than 10 years (Table III), and 11 patients dead more than 10 years after operation (Table IV).

\section{PERIOD 5 TO 10 YEARS AFTER OPERATION}

64 LIVING PATIENTS Of these, 47 (73.4\%) remained well from the time of operation with an existence comparable in quality to that of their age group. The remaining 17 patients developed a disease or complaint after the fifth year. Some developed more than one, which accounts for the apparent discrepancy in the figures presented. Four patients had further surgery-a pyloroplasty for benign pyloric stenosis eight years after operation, a cataract operation six years after, a prostatectomy for benign hypertrophy six years after, and a hemi-thalectomy for uncontrolled tonic spasms of the arm muscles carried out six years after lobectomy. One patient developed hypertension, one diabetes, and one carcinomatosis. Two patients required psychiatric treatment for mental depression in their sixth and eighth post-operative years. Two patients developed swelling of the left arm and superior vena caval obstruction considered incorrectly to be caused by mediastinal metastases. Both exhibited marked displacement of the mediastinum after pneumonectomy, and in both the condition resolved. One patient was investigated eight years after pneumonectomy for a persistent segmental atelectasis in the opposite lung, thought to be due to a second primary lung tumour. After three months the radiological shadow resolved. This was the only patient in whom a suspicion of a second primary lung carcinoma was not subsequently confirmed. One patient developed a contralateral effusion eight years after lobectomy. The effusion has persisted over 12 months and the cause has not been established. One patient developed an ipsilateral Morgagni hernia six years after lobectomy. Four patients adapted unsatisfactorily to post-resection life, three, known pre-operative bronchitics, because of increasing dyspnoea 6, 9, and 9 years 
after operation, and one because of depression. Three patients are at the present time regarded as badly adapted in the sense that, although apparently able to carry out their former occupation, they have not worked since operation. No organic lesion prevents them taking their place in society; each was under the age of 50 at operation 9,9 , and 8 years ago. They are of inadequate personality though not mentally ill, and complain intermittently of chest pain when challenged concerning their idleness. They are known to take part occasionally in vigorous lucrative casual work. These patients' present state in part represents the clinicians' disinclination to become involved in the rehabilitation, after operation, of patients of this calibre, with the result that much of the benefit of the operation is irretrievab.y lost and the patient's discontent remains. One patient, working six years after, had a non-curative pneumonectomy in which residual tumour remained on the stump of the left pulmonary artery at operation. Six patients had extended operations, three in whom portions of the trachea were resected, two after pneumonectomy with atrial wall resection, and one (patient 9, Table I) a sleeve resection of the main bronchus and left upper lobe combined with excision of a sleeve of the main pulmonary artery because of extension of the tumour into the arterial wall. No patient survived five years who had an extended lung resection associated with carinal resection ( 3 cases), local oesophageal resection ( 2 cases), simultaneous oesophagectomy ( 2 cases $)$, or superior vena caval resection and insertion of prosthesis ( 5 cases). Details of 10 -year survivors $\stackrel{\vec{F}}{+}$ from extended and non-curative resection will be? presented. No patient with lymph node involve- $\frac{O}{\bar{c}}$ ment at operation, and of cell type other than squamous, lived five years.

38 DEAD PATIENTS In the 5-10 year period, threedied from primary extrathoracic carcinoma (TableI), 20 from lung carcinoma (Table IIA), and $15 \vec{w}$ from other causes (Table IIB).

The nature of the fresh carcinoma in the $20 \vec{x}$ patients was classified as fresh lung primary in ज six patients, the most frequent manner in whichlung carcinoma reappeared. In the 5-10 yearo period stump recurrence was observed only aftero lobectomy and never after pneumonectomy. Only. one patient with stump recurrence was operatede upon a second time (patient 14, Table IIA). Mores patients should have been treated by operation Each of the 20 tumours detailed in Table IIA was of a squamous-cell type.

Of 15 dying from other causes, 10 were due too progressive lung or heart disease, and 5 (patientso $7,9,10,11$, and 12, Table IIB) from causes? apparently entirely unrelated to operation. Onepatient (patient 5, Table IIB) had a non-curativen resection; a portion of squamous-cell tumour. about the size of a cherry, could not be resected? from the left atrium because of the extent of the tumour on the atrial wall. An incision had to be made through the tumour to free the lung and enable the resection to be completed. At autopsy following the sudden death of this patient seven years later, no trace of this residual tumour could

T A B L E I

DEVELOPMENT OF INDEPENDENT PRIMARY CARCINOMA IN SITE OTHER THAN LUNG

\begin{tabular}{|c|c|c|c|c|c|c|}
\hline Patient & Lung Op. & $\begin{array}{c}\text { Site of } \\
\text { Independent Primary }\end{array}$ & $\begin{array}{c}\text { Interval } \\
\text { between Lung } \\
\text { Op. and } \\
\text { Independent } \\
\text { Primary } \\
\text { (yrs) }\end{array}$ & Treatment & Present State & $\begin{array}{c}\text { Interval since } \\
\text { Lung Op. } \\
\text { (yrs) }\end{array}$ \\
\hline 1 & $\begin{array}{l}\text { L.P. } 1955 \\
(\mathrm{~N} / \mathrm{C})\end{array}$ & Prostate & 10 & $\begin{array}{l}\text { Prostatectomy; colostomy } \\
\text { for vesico-colic fistula }\end{array}$ & $\begin{array}{l}\text { Alive (same pt. } \\
\text { as pt. } 7 \text {, } \\
\text { Table III) }\end{array}$ & 14 \\
\hline 2 & $\begin{array}{l}\text { R.U.L. } 1956 \\
\text { L.L.L. (seg) } \\
1964\end{array}$ & Descending colon & $\begin{array}{l}13 \\
\text { (since first } \\
\text { operation) }\end{array}$ & $\begin{array}{l}\text { Colostomy + resection. } \\
\text { Died, pneumonia, } 5 / 52 \\
\text { post-op. }\end{array}$ & $\begin{array}{l}\text { Dead (same pt. } \\
\text { as pt. 6, } \\
\text { Table IV) }\end{array}$ & 13 \\
\hline $\begin{array}{l}3 \\
4\end{array}$ & $\begin{array}{l}\text { R.U.L. } 1957 \\
\text { R.U.L. } 1957\end{array}$ & $\begin{array}{l}\text { Oesophagus } \\
\text { Epithelioma, lip }\end{array}$ & $\begin{array}{l}7 \\
2\end{array}$ & $\begin{array}{l}\text { Palliative intubation } \\
\text { Excision }\end{array}$ & $\begin{array}{l}\text { Dead } \\
\text { Alive }\end{array}$ & $\begin{array}{r}7 \\
12\end{array}$ \\
\hline 5 & R.U.L. 1958 & Stomach & 8 & Gastrectomy & $\begin{array}{l}\text { Alive (same pt. } \\
\text { as pt. } 30, \\
\text { Table III) }\end{array}$ & 11 \\
\hline 6 & R.P. 1958 & $\begin{array}{l}\text { Malignant melanoma } \\
\text { of leg }\end{array}$ & 8 & $\begin{array}{l}\text { Excision. Died, pulmonary } \\
\text { embolus, post-op. }\end{array}$ & Dead & 8 \\
\hline 7 & L.L.L. 1961 & Ampulia of Vater & 6 & Laparotomy and biopsy & Dead & 6 \\
\hline 8 & L.U.L. 1962 & Rectum & 2 & $\begin{array}{l}\text { Conservative resection of } \\
\text { rectum }\end{array}$ & Dead & 3 \\
\hline 9 & $\begin{array}{l}\text { L.U.L. } 1964 \\
\text { (sleeve) }\end{array}$ & Body of uterus & 2 & $\begin{array}{l}\text { Total hysterectomy and } \\
\text { radium }\end{array}$ & Alive & 5 \\
\hline
\end{tabular}

L.P. = Left pneumonectomy; R.P. = right pneumonectomy; R.U.L. =right upper lobectomy; L.L.L.=left lower lobectomy; L.U.L. =lefe upper lobectomy. 
T A B L E I I A

20 PATIENTS DYING OF LUNG CARCINOMA 5-10 YEARS AFTER OPERATION

\begin{tabular}{|c|c|c|c|c|c|c|}
\hline Patient & $\begin{array}{c}\text { Age at } \\
\text { Operation }\end{array}$ & Operation 1 & Nature of Fresh Carcinoma & $\begin{array}{c}\text { Method of Confirmation } \\
\text { of Diagnosis }\end{array}$ & $\begin{array}{c}\text { Carcinoma Diag- } \\
\text { nosed as Present } \\
\text { or Absent on } \\
\text { Completion of } \\
\text { 5th Post-operative } \\
\text { Year }\end{array}$ & $\begin{array}{l}\text { Interval } \\
\text { between } \\
\text { Operation } \\
\text { and Death } \\
\text { (yrs) }\end{array}$ \\
\hline $\begin{array}{r}1 \\
2 \\
3 \\
4 \\
5 \\
6 \\
7 \\
8 \\
9 \\
10 \\
11 \\
12 \\
13 \\
14 \\
15 \\
16 \\
17 \\
18 \\
19 \\
20\end{array}$ & $\begin{array}{l}60 \\
46 \\
60 \\
56 \\
52 \\
61 \\
71 \\
57 \\
56 \\
63 \\
60 \\
48 \\
58 \\
52 \\
52 \\
58 \\
58 \\
52 \\
64 \\
58\end{array}$ & $\begin{array}{l}\text { L.P. } \\
\text { L.P. } \\
\text { R.U.L. } \\
\text { L.L.L. } \\
\text { R.L.L. } \\
\text { R.L.L. } \\
\text { L.L.L. } \\
\text { L.L.L. } \\
\text { R.P. } \\
\text { R.U.L. } \\
\text { R.U.L. } \\
\text { R.L.L. } \\
\text { R.U.L. } \\
\text { R.L.L. } \\
\text { R.P. } \\
\text { L.L.L. } \\
\text { L.P. } \\
\text { R.L.L. } \\
\text { R.U.L. } \\
\text { R.U.L. } \\
\text { (sleeve) }\end{array}$ & $\begin{array}{l}\text { 2nd primary } \\
\text { 2nd primary } \\
\text { Mediastinal extension } \\
\text { Stump recurrence } \\
\text { 2nd primary } \\
\text { Single liver secondary } \\
\text { 2nd primary } \\
\text { Stump recurrence } \\
\text { Carcinomatosis } \\
\text { Mediastinal extension } \\
\text { Stump recurrence } \\
\text { Extension of tumour in lung } \\
\text { 2nd primary } \\
\text { Stump recurrence } \\
\text { Mediastinal extension } \\
\text { Extension of tumour in lung } \\
\text { Recurrence in trachea } \\
\text { 2nd primary } \\
\text { Stump recurrence } \\
\text { Recurrence at suture line }\end{array}$ & $\begin{array}{l}\text { Autopsy } \\
\text { + ve bronchoscopic biopsy } \\
\text { + ve neck gland biopsy } \\
\text { + ve bronchoscopic biopsy } \\
\text { Re-operation } \\
\text { Autopsy } \\
\text { + ve bronchoscopic biopsy } \\
\text { + ve bronchoscopic biopsy } \\
\text { Gland in groin } \\
\text { Autopsy } \\
\text { + ve bronchoscopic biopsy } \\
\text { Re-operation } \\
\text { Re-operation } \\
\text { Re-operation } \\
\text { Clinical } \\
\text { Clinical } \\
\text { + ve bronchoscopic biopsy } \\
\text { Re-operation } \\
\text { + ve bronchoscopic biopsy } \\
\text { + ve biopsy and autopsy }\end{array}$ & $\begin{array}{l}\text { Absent } \\
\text { Absent } \\
\text { Absent } \\
\text { Present } \\
\text { Present } \\
\text { Absent } \\
\text { Absent } \\
\text { Absent } \\
\text { Absent } \\
\text { Absent } \\
\text { Absent } \\
\text { Present } \\
\text { Absent } \\
\text { Absent } \\
\text { Present } \\
\text { Present } \\
\text { Absent } \\
\text { Present } \\
\text { Absent } \\
\text { Absent }\end{array}$ & $\begin{array}{l}9 \\
9 \\
8 \\
8 \\
7 \\
7 \\
7 \\
7 \\
6 \\
6 \\
6 \\
6 \\
6 \\
6 \\
5+ \\
5+ \\
5+ \\
5+ \\
5+ \\
5+\end{array}$ \\
\hline
\end{tabular}

Patient 2-female.

1 For abbreviations see Table I.

T A B L E I I B

15 PATIENTS DYING OF CAUSES OTHER THAN CARCINOMA 5-10 YEARS AFTER OPERATION

\begin{tabular}{|c|c|c|c|c|c|c|c|}
\hline Patient & $\begin{array}{c}\text { Age at } \\
\text { Operation }\end{array}$ & Operation ${ }^{1}$ & Cause of Death & & & $\begin{array}{l}\text { Method of } \\
\text { Confirmation of } \\
\text { Absence of } \\
\text { Carcinoma }\end{array}$ & $\begin{array}{c}\text { Interval } \\
\text { between } \\
\text { Operation and } \\
\text { Death (yrs) }\end{array}$ \\
\hline $\begin{array}{r}1 \\
2 \\
3 \\
4 \\
5 \\
6 \\
7 \\
8 \\
9 \\
10 \\
11 \\
12 \\
13 \\
14 \\
15\end{array}$ & $\begin{array}{l}53 \\
55 \\
59 \\
56 \\
56 \\
58 \\
62 \\
63 \\
62 \\
58 \\
58 \\
60 \\
59 \\
61 \\
60\end{array}$ & $\begin{array}{l}\text { Segmental } \\
\text { R.U.L. } \\
\text { L.P. } \\
\text { R.U.L. } \\
\text { L.P. (N/C) } \\
\text { R.U.L. } \\
\text { R.U.L. } \\
\text { L.U.L. } \\
\text { L.P. (N/C) } \\
\text { R.P. } \\
\text { L.P. } \\
\text { R.U.L. } \\
\text { Segmental } \\
\text { L.U.L. } \\
\text { R.P. }\end{array}$ & $\begin{array}{l}\text { Status asthmaticus } \\
\text { Haemoptysis } \\
\text { Recurrent chest infection } \\
\text { Cor pulmonale } \\
\text { Coronary thrombosis } \\
\text { Recurrent chest infection } \\
\text { Ruptured abdominal aneurysm } \\
\text { Atrial fibrillation; cardiac failure } \\
\text { Cerebrovascular accident } \\
\text { Peritonitis, unknown source } \\
\text { Hypertensive encephalopathy } \\
\text { Jaundice .. } \\
\text { Coronary thrombosis } \quad \ldots \\
\text { Tuberculosis of lung } \\
\text { Left ventricular failure }\end{array}$ & $\begin{array}{l}\cdots \\
\cdots \\
\cdots \\
\cdots \\
\cdots \\
\cdots \\
\cdots \\
\cdots \\
\cdots \\
\cdots\end{array}$ & $\begin{array}{l}\cdots \\
\cdots \\
\cdots \\
\cdots \\
\cdots \\
\cdots \\
\cdots \\
\cdots \\
\cdots \\
\cdots\end{array}$ & $\begin{array}{l}\text { Clinical } \\
\text { Clinical } \\
\text { Autopsy } \\
\text { Clinical } \\
\text { Autopsy } \\
\text { Clinical } \\
\text { Autopsy } \\
\text { Clinical } \\
\text { Clinical } \\
\text { Autopsy } \\
\text { Autopsy } \\
\text { Autopsy } \\
\text { Autopsy } \\
\text { Clinical } \\
\text { Autopsy }\end{array}$ & $\begin{array}{l}9 \\
8 \\
8 \\
8 \\
7 \\
7 \\
7 \\
6 \\
6 \\
6 \\
6 \\
5 \\
5 \\
5\end{array}$ \\
\hline
\end{tabular}

Each patient's last chest radiograph essentially unchanged since operation.

1 For abbreviations see Table I.

be found on or around the atrium on gross or histological examination of the specimen. No tumour was present in the rest of the body. No autopsy was possible on the other patient (patient 9), who died from a cerebral haemorrhage six years after a non-curative resection.

\section{PERIOD 10 YEARS OR MORE AFTER OPERATION}

38 LIVING PATIENTS Of these, $20(51 \cdot 3 \%)$ remained well throughout, developed no other disease, and remained well adapted to post-resection life, without significant reduction in respiratory function. The quality of their survival was wholly accept- able to the patient. Eighteen developed a disease or symptom (Table III). The date at which the disease first appeared is given when possible. Seven patients had further operations-two for hypertrophy of the prostate (patients 13 and 36), three for fresh carcinoma (patients 7, 22, and 30), and one for adenoma of the thyroid (patient 26). Two developed ischaemic heart disease (patients 1 and 32), associated with hypertension in one patient. Two required psychiatric treatment (patients 8 and 16), one from the time of the operation because of pethidine addiction. One suffered a cerebrovascular accident with mild 
T A B L E I I I

38 PATIENTS LIVING MORE THAN 10 YEARS AFTER OPERATION

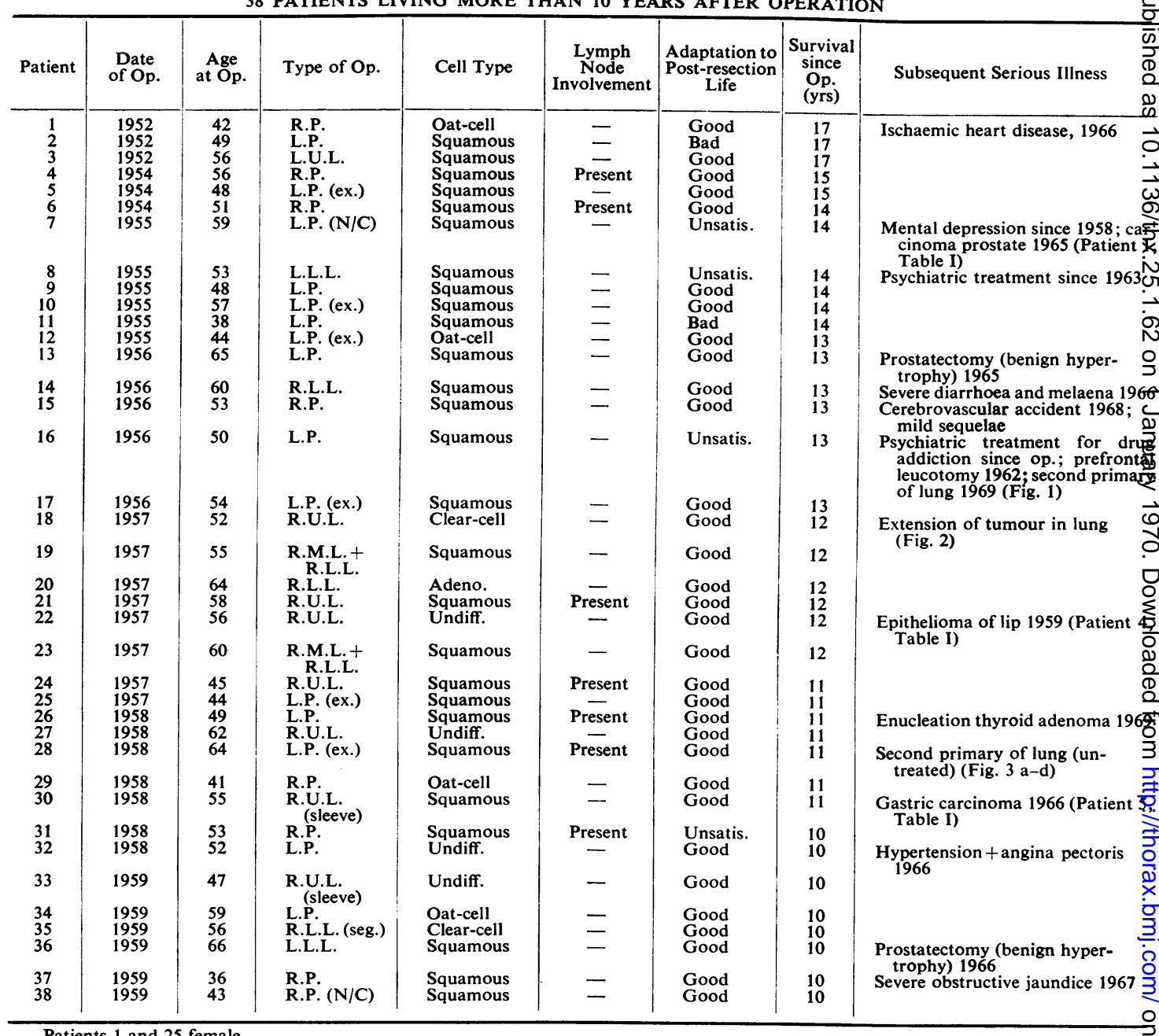

Patients 1 and 25 female.

residual sequelae. Three are alive with evidence of fresh lung carcinoma (patients 16, 18, and 28) (Figs 1 and 2).

Two patients developed symptoms suggestive of intra-abdominal carcinoma and both were investigated in hospital (patients 14 and 37). One was considered to have developed a carcinoma of the colon, and the other metastases in the liver. Investigation was negative, symptoms subsided, and both returned to their previous activity. In four patients $(7,8,16$, and 31$)$ adaptation to postresection life was considered unsatisfactory, in three patients because of psychiatric symptoms and in the other (patient 31 ) because of increasing shortness of breath from the fifth post-operative year. In two patients (2 and 11) adaptation was bad. Neither showed any sign of organic disease They were aged 49 and 38 at the time of pneuw monectomy 17 and 14 years previously. They have not worked since operation and seem content tos accept a reduced standard of living.

Table III shows four patients with oat-celf ${ }^{?}$ tumour and seven patients with hilar node in $\frac{0}{T}$ volvement alive more than 10 years after opera $\frac{0}{\mathbb{Q}}$ tion. Two patients underwent pneumonectomy op the non-curative type. Both had squamous-cellecb tumours only partially resected from the lefo atrium. The portion of tumour remaining on then 


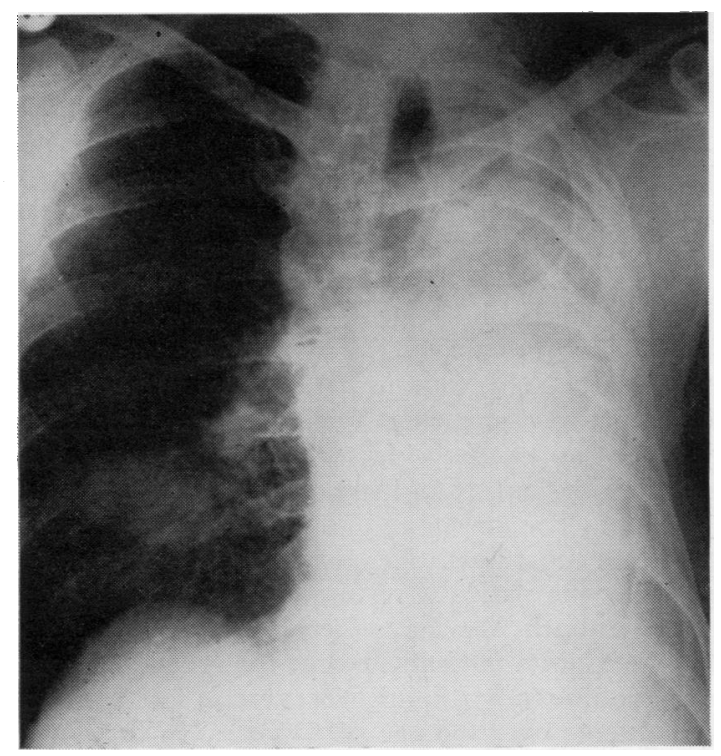

FIG. 1. (Patient 16, Table III.) Chest radiograph 13 years after left pneumonectomy, showing second primary carcinoma in right lower lobe. Patient alive.

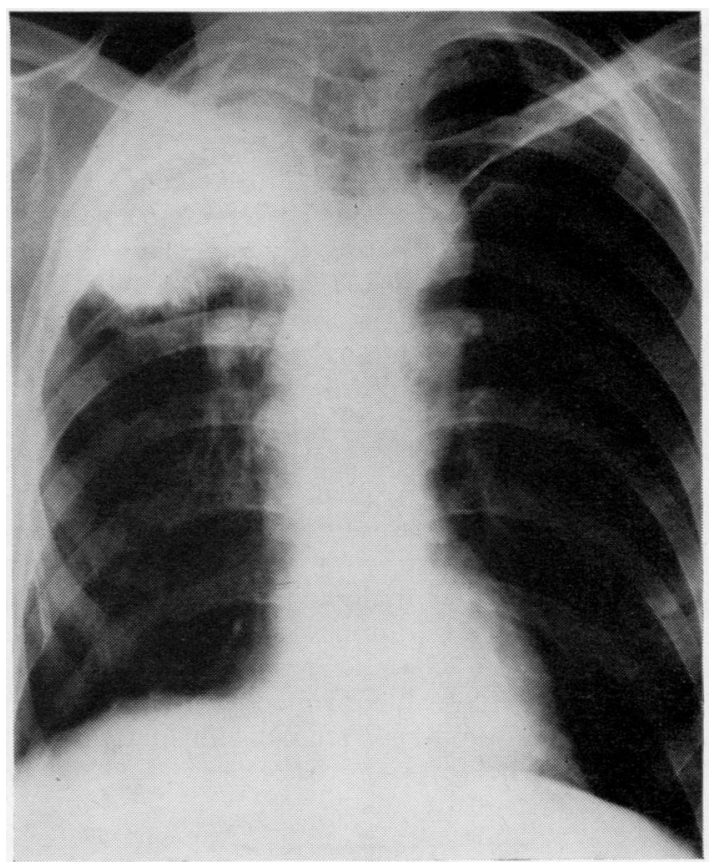

FIG. 2. (Patient 18, Table III.) Chest radiograph 12 years after right upper lobectomy, showing extension of tumour. Patient alive. Biopsy positive.

T A B L E I V

11 PATIENTS DYING MORE THAN 10 YEARS AFTER OPERATION

\begin{tabular}{|c|c|c|c|c|c|c|c|c|c|}
\hline Patient & $\begin{array}{l}\text { Date } \\
\text { of Op. }\end{array}$ & $\begin{array}{l}\text { Age } \\
\text { at } \\
\text { Op. }\end{array}$ & $\begin{array}{l}\text { Type } \\
\text { of Op. }\end{array}$ & $\begin{array}{l}\text { Cell } \\
\text { Type }\end{array}$ & $\begin{array}{l}\text { Lymph Node } \\
\text { Involvement }\end{array}$ & $\begin{array}{c}\text { Adaptation } \\
\text { to Post- } \\
\text { resection } \\
\text { Life }\end{array}$ & $\begin{array}{c}\text { Interval } \\
\text { between } \\
\text { Operation } \\
\text { and Death } \\
\text { (yrs) }\end{array}$ & $\begin{array}{l}\text { Cause of } \\
\text { Death }\end{array}$ & $\begin{array}{l}\text { Method of } \\
\text { Confirmation } \\
\text { of Diagnosis }\end{array}$ \\
\hline $\begin{array}{l}1 \\
2\end{array}$ & $\begin{array}{l}1951 \\
1953\end{array}$ & $\begin{array}{l}50 \\
57\end{array}$ & $\begin{array}{l}\text { L.P. (ex) } \\
\text { L.U.L. }\end{array}$ & $\begin{array}{l}\text { Squamous } \\
\text { Squamous }\end{array}$ & - & $\begin{array}{l}\text { Good } \\
\text { Unsatis. }\end{array}$ & $\begin{array}{l}12 \\
13\end{array}$ & $\begin{array}{l}\text { 2nd primary } \\
\text { Cor pulmonale }\end{array}$ & $\begin{array}{l}\text { Radiological } \\
\text { Autopsy }\end{array}$ \\
\hline 3 & 1953 & 55 & L.P & Squamous & - & Unsatis. & 12 & Cor pulmonale & Clinical \\
\hline 4 & 1954 & 62 & L.U.L. & Squamous & Present & Bad & 10 & 2nd primary & Radiological + \\
\hline 5 & 1955 & 56 & L.L.L. & Squamous & - & Good & 10 & 2nd primary & Radiological + \\
\hline 6 & $\begin{array}{l}1956 \\
1964\end{array}$ & $\begin{array}{l}59 \\
67\end{array}$ & $\begin{array}{l}\text { R.U.L. } \\
\text { L.L.L. } \\
\quad \text { (seg) }\end{array}$ & $\begin{array}{l}\text { Squamous } \\
\text { Squamous }\end{array}$ & - & $d$ & $\begin{array}{l}13 \text { (since } \\
1 \text { st op.) }\end{array}$ & $\begin{array}{l}\text { Carcinoma } \\
\text { colon; had 3rd } \\
\text { primary lung }\end{array}$ & $\begin{array}{l}\text { Laparotomy }+ \\
\text { autopsy } \\
\text { (Fig. 5) }\end{array}$ \\
\hline 7 & 1956 & 55 & L.P. & Squamous & - & Good & 11 & 2nd primary & Radiological + \\
\hline 8 & 1956 & 62 & L.U.L. & Squamous & Present & Good & 11 & Coronary & Autopsy \\
\hline 9 & 1957 & 58 & R.P. & Squamous & - & Unsatis. & 11 & Cardiovascular & Clinical \\
\hline 10 & 1957 & 36 & L.L.L. & $\begin{array}{l}\text { Alveolar } \\
\text { cell }\end{array}$ & - & Good & 11 & 2nd primary & $\begin{array}{l}\text { Autopsy } \\
\text { (Fig } 4 \text { a-d) }\end{array}$ \\
\hline 11 & 1958 & 60 & L.U.L. & Squamous & - & Unsatis. & 10 & $\begin{array}{l}\text { Psychiatric } \\
\text { cause }\end{array}$ & No autopsy \\
\hline
\end{tabular}


atrium in both patients apparently has undergone resolution in a similar manner to that of patient 5 (Table IIB).

11 DEAD PATIENTS Details are shown in Table IV. Five patients $(1,4,5,7$, and 10) died of second primary lung tumours. No patient developed any other illness. Four patients adapted unsatisfactorily to post-resection life, three from increasing dyspnoea from the time of operation, and one (patient 11) from minor mental illness which fina'ly appeared to cause the patient's death from an acute depressive state. One patient (patient 4) never returned to work, for no obvious reason. One patient (patient 1) died 12 years after an extended operation when a portion of the left diaphragm was removed with the lung. There was probably no actual malignant infiltration of the diaphragm, but separation was not possible. One patient (patient 6) died after resection of a carcinoma of the colon, having had resection of two separate lung primaries. Details of this patient will be presented below.

\section{DISCUSSION}

QUALITY OF SURVIVAL A study of Tables III and IV reveals that adaptation to post-resection life was good in 38 of the 49 patients surviving more than 10 years. Of these 38 patients, 20 underwent pneumonectomy. Our criteria for considering adaptation to be good were non-specific. If a patient was observed to be consistently able to compete on near level terms with his fellows, he was placed in this category. Feinmann (1960), in a detailed study of the respiratory function of 31 patients surviving more than five years after operation, pointed out that employment was not a sensitive index of pulmonary function and that factors other than function had to be considered in assessing the patients' post-operative state. Ogilvie, Harris, Meecham, and Ryder (1963) studied 12 out of 15 patients who survived more than 10 years after pneumonectomy. They considered reduction in ventilatory capacity was more likely due to a deficient bellows action of the ribs than to degenerative lung changes. Our results confirm that pneumonectomy may be compatible with worth-while long-term survival. Constant supervision of the patient in the outpatient department contributed something to these results. The recognition and treatment of second lung primaries or tumours elsewhere, advice on the early treatment of infection in the lung, and the suitability of the patient's work with increasing age and diminution of pulmonary function are? obvious advantages. Scrutiny of the work recorf of 10-year survivors is interesting. No patien among the 10-year survivors had a prolonge period away from work once he returned follow ing operation. A patient either never returned t $\odot$ work or continued to work, disregarding break $\vec{\Phi}$ for trivial ailments, throughout the survivat period. When a prolonged break occurred, fog example, throughout the third or fourth year, suct a patient did not survive to 10 years. In other words, a prolonged work break in a patient preer viously willing and able to work was a bad prog $\vec{\cdot}$ nostic sign for survival to 10 years, due usuallyo to extension of tumour. It was surprising how infrequently increasing age enforced the patient to stop work. As a factor seriously interfering with the patient's life, increasing dyspnoea was in? frequent. The onset and severity of dyspnoea in the later post-operative years will primarily de pend on the patient's respiratory state at the time of operation. We have been selective and noP operated upon patients, except for special reasons with significantly diminished exercise tolerance, of on patients over the age of 65 years. In the whols series of 964 patients, only six were over 65 ag the time of operation. It is clear that a patient, $i \mathbb{D}$ judged fit for pneumonectomy, may live man years after operation without significant deteriora응 tion in exercise tolerance. Our results confirm the findings of Watson (1965). In his informative re view of 49 patients surviving resection by $1 \dot{\phi}$ years, 35 of whom underwent pneumonectomy he stated, 'one might expect a very high incidence of cor pulmonale, right heart failure, and related cardiovascular causes of death. The data do no support this theory'.

CAUSE OF DEATH The main facts concerning the cause of death are tabulated. We shall concentrate in this discussion particularly on carcinoma as the cause. Respiratory deaths were not frequent.

At the present time one can assume that the patient may possess or develop or lose resistanced or immunity to the tumour, and that this accounts for the variability in progress of apparently simio lar tumours. Furthermore, it can be assumed thato when resistance is low, a condition of generalize carcinomatosis may exist from the outset, and when high, the patient confines the tumour locallyo for variable periods of time, allowing resection of the gross tumour and possible cure. The late manifestations of carcinoma have been described by such terms as fresh primaries, recurrences $\cong$ metastases or extension of the original tumour by 

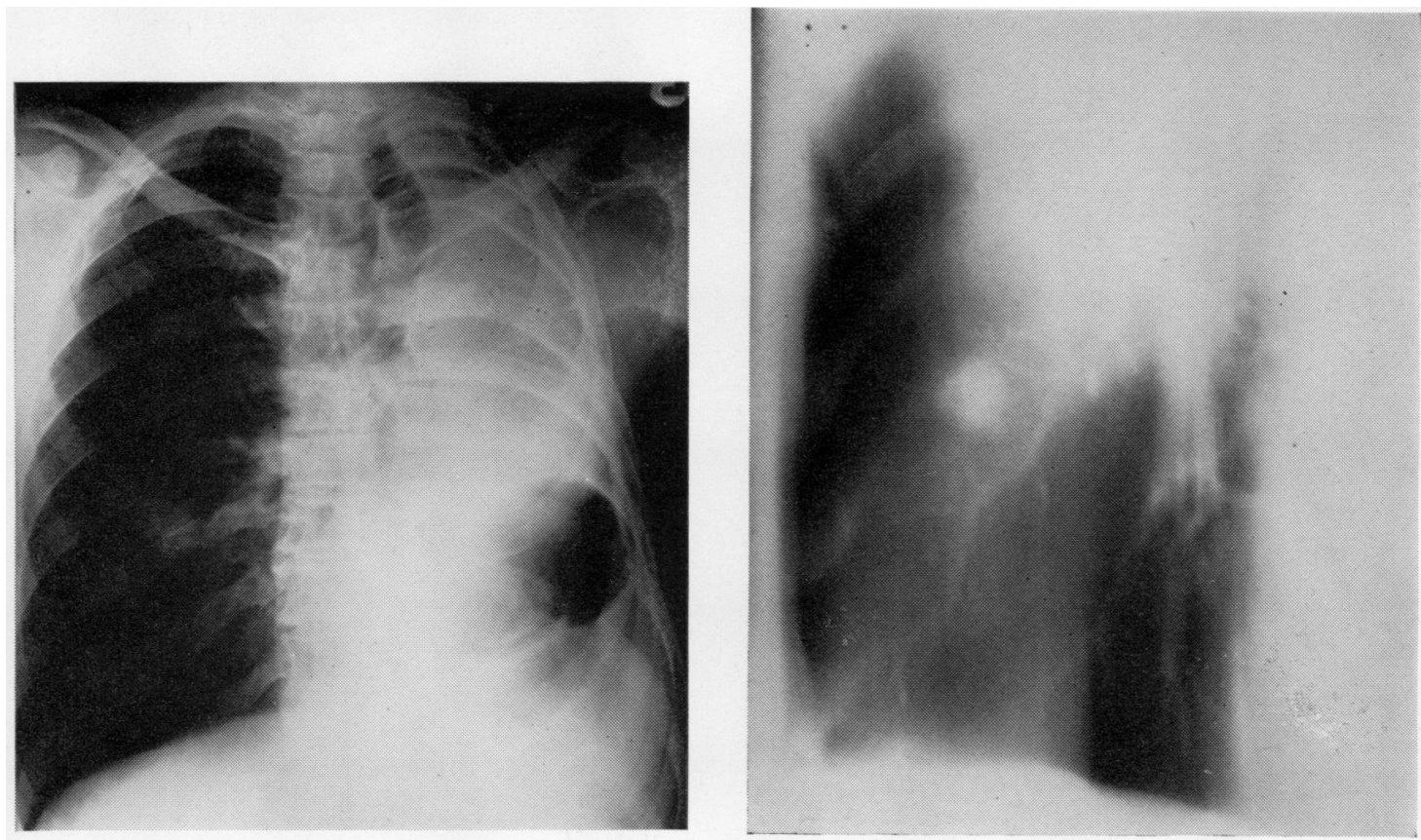

(a)

(b)
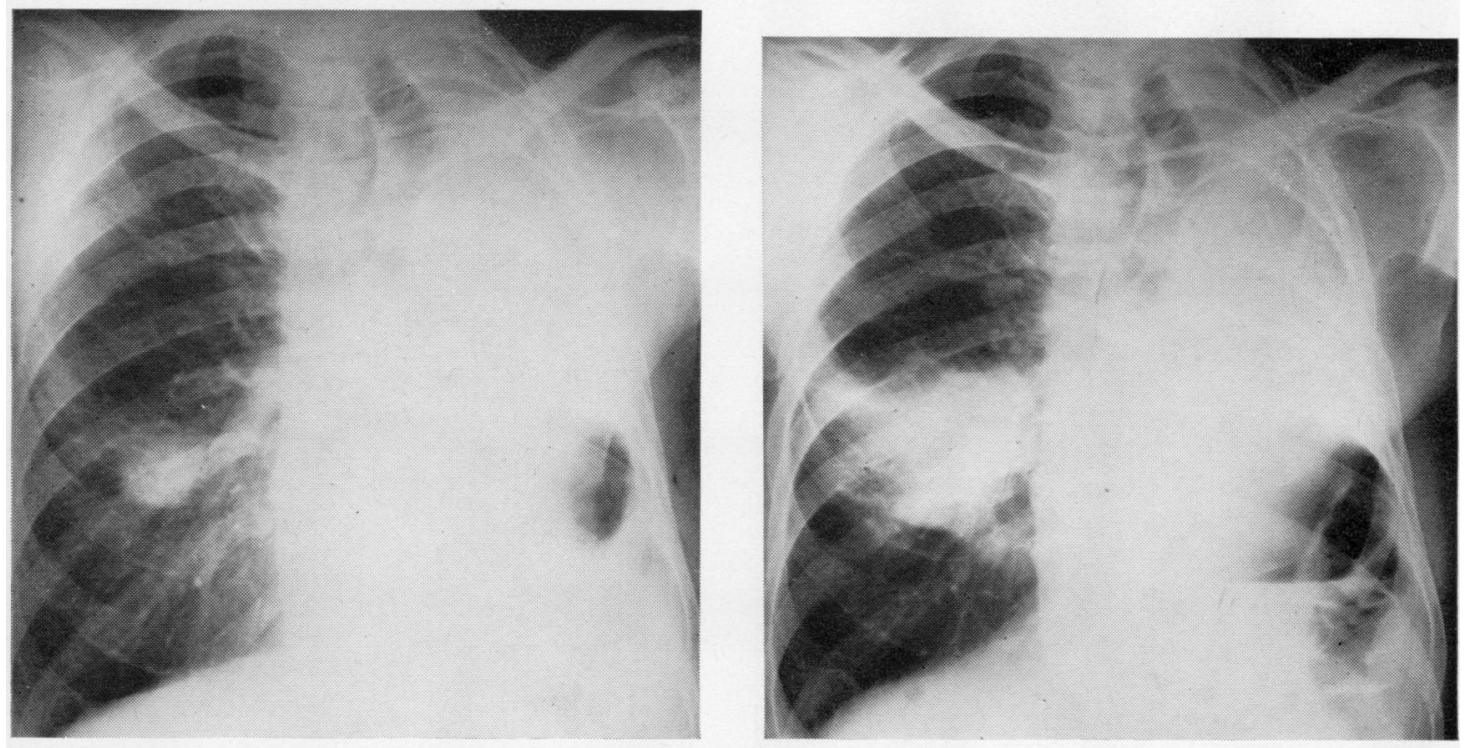

(c)

(d)

FIG. 3. (Patient 28, Table III, A.H. in text.) (a) Chest radiograph in 1964, six years after extended left pneumonectomy, showing second primary carcinoma in right lung. (b) Tomographic appearance in 1964. (c) Chest radiograph in 1966. (d) Chest radiograph in 1969. Patient alive. Squamous cells in sputum. 


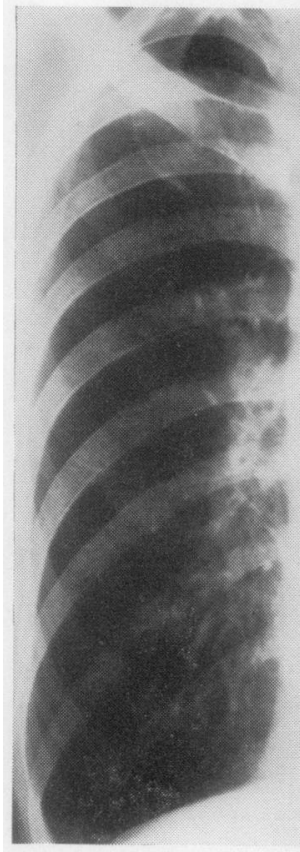

(a)

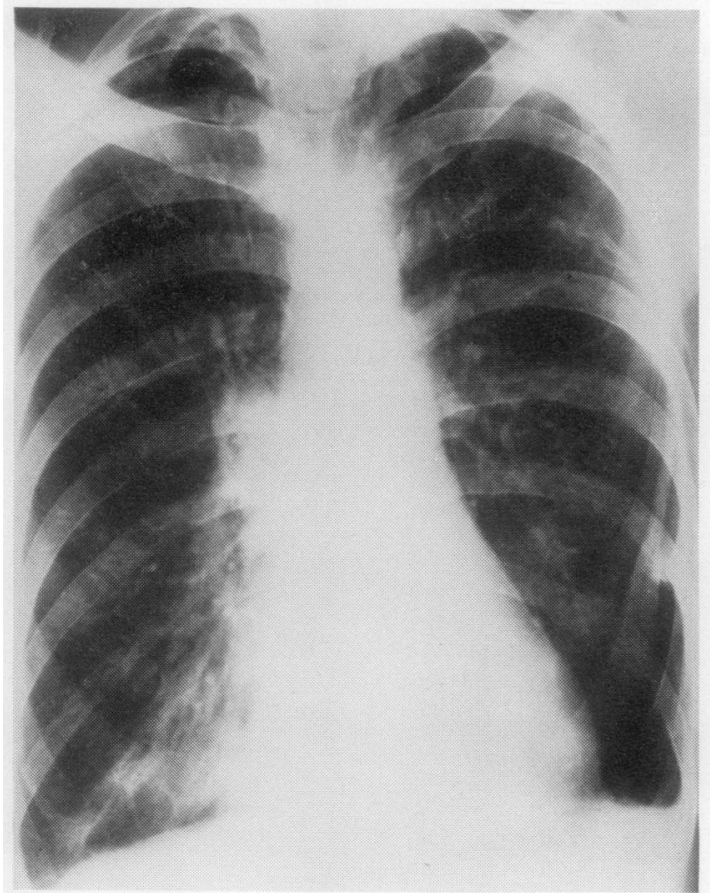

(c)

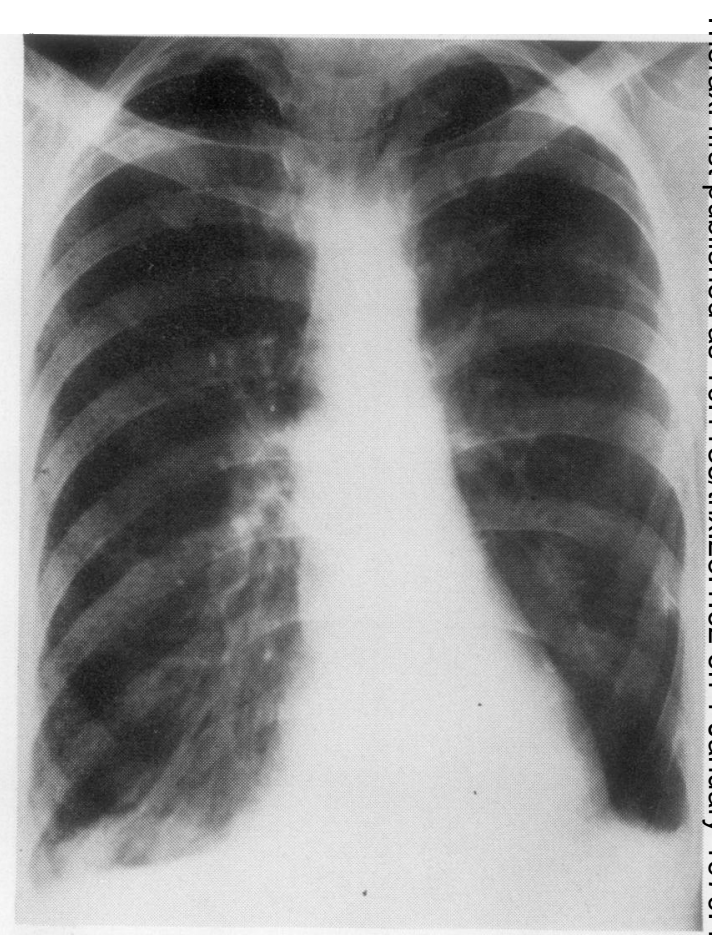

(b)

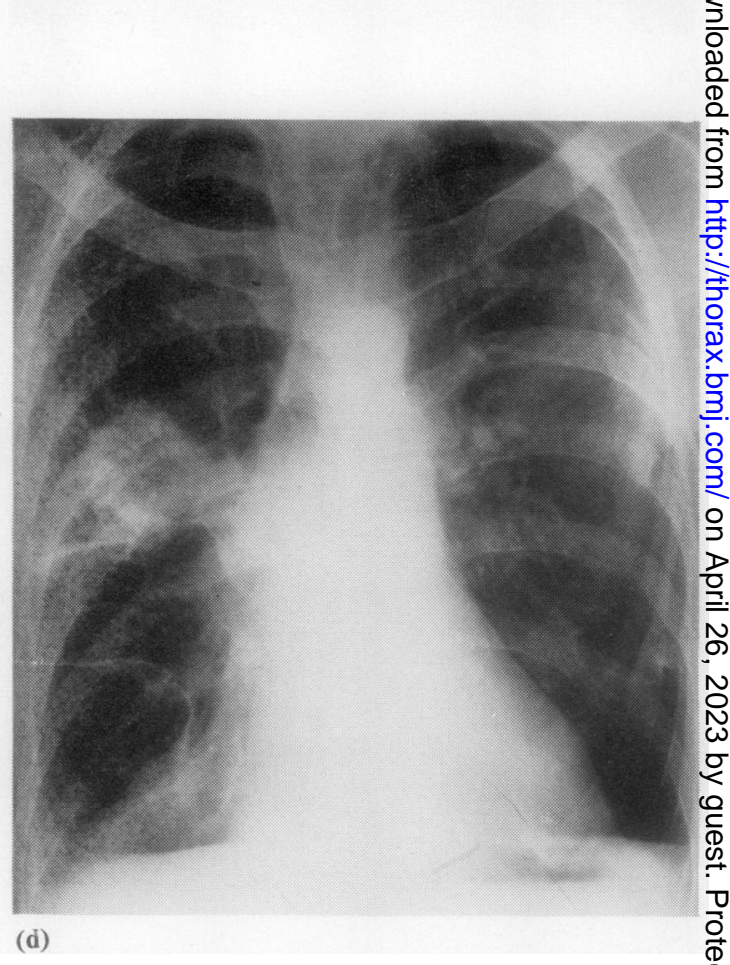

(d)

FIG. 4. (Patient 10, Table IV, J.R. in text.) (a) Chest radiograph in 1957 at time of left lower lobectomy. (b) Chest $\frac{\rho}{\mathbb{D}}$ radiograph in 1962, five years after lobectomy. Tentative diagnosis of fresh second primary right lower lobe. (c) Chest $\varrho$ radiograph in April 1968. No significant change from Fig. 4(b). (d) Chest radiograph in August 1968. Fresh right ${ }^{\circ}$ upper lobe shadow. Patient dead, see text for autopsy findings. 
different authors. Watson (1965) described five patients dying of recurrent lung cancer and one of second lung primary more than 10 years after resection; Le Roux (1968) reported six patients alive 9 to 12 years after pneumonectomy in whom the tumour had recurred, and Belcher and Anderson (1965) reported two of their 10-year survivors dying of metastases 10 and 12 years after operation. We have attempted to separate, for reasons outside the scope of this discussion, any fresh evidence of carcinoma into the groups detailed in Table IIA. In fact, if the concept of patients' resistance to the tumour is accepted, it is perhaps not important to classify the fresh carcinoma by name, if and when it appears. What is important is to establish, without offering reasons, that resistance is a variab'e factor which alters for unknown reasons, and allows tumour-cell aggregation within the body to assume the proportions of clinical cancer at any period after the original operation, or indeed before any operation is performed. We know of no other explanation to account for the behaviour of some tumours, other than assuming that resistance is variable, both in intensity and at different time periods, throughout the post-operative period of observation in those patients in whom fresh tumour appears. We shall attempt to establish this variability by presentation of case histories and by statistical analysis of the results.

\section{CASE HISTORIES}

A. H. (patient 28, Table III) In 1964, six years after an extended pneumonectomy when a portion of the atrium was resected, a diagnosis of a second lung primary was made. The radiographs are shown (Fig. 3 a-d). Five years after the first radiological evidence of a second primary, the patient has no real symptoms. He is now 74 years of age and, against medical advice, still drives his motor car. The interest in this patient lies in the delay in progress of this tumour. If breakdown in patient resistance explains the appearance of a second clinical carcinoma, it is odd that its progress should be so slow. Diminished resistance should be associated with rapid progress.

J.R. (patient 10, Table IV) In 1957, at the age of 36 , this patient underwent left lower lobectomy for a bronchiolar cell carcinoma (Fig. 4a). Five years later a fresh radiological shadow appeared (Fig. 4b). A tentative diagnosis of a second lung primary in the right lower lobe was made. For various reasons exploration was not advised and follow-up continued. In April 1968, 11 years after operation, the patient was well and, although the right lower zone was not normal, no significant change was visible
(Fig. 4c). In August 1968 the patient complained of chest pain, and the radiograph revealed a large right upper lobe opacity (Fig. 4d). Within eight weeks the patient died of carcinomatosis, including spread to ribs, sternum, and mandible. At autopsy a bronchiolar-cell tumour was present in both the right upper lobe and the right lower lobe, the latter corresponding to the shadow detected in 1961. There was considerable microscopic difference between the two tumours; the lower lobe tumour was better differentiated than the other, and it was encapsulated by a thick layer of collagen on the overlying pleura. It seemed an acceptable proposition that the lower lobe tumour was the cause of the shadow visible in the 1961 radiograph, and certain that the upper lobe tumour caused the upper lobe shadow. The interest lies in the strong possibility of the lower lobe tumour lying dormant for seven years between 1961 and 1968 , the appearance of a further tumour from some abrupt breakdown in resistance apparently being responsible for the rapid death of the patient within eight weeks of the first radiological evidence of its presence. One can only assume that the carcinomatosis was related to the appearance of the upper lobe lesion. A number of reasons exist for this assumption, but no adequate explanation in terms of the patient-tumour relationship is possible.

W.D. (patient 6, Table IV) Following a curative right upper lobectomy in 1955 , the patient remained well with normal chest radiograph appearance for eight years. Four months after a normal chest radio-

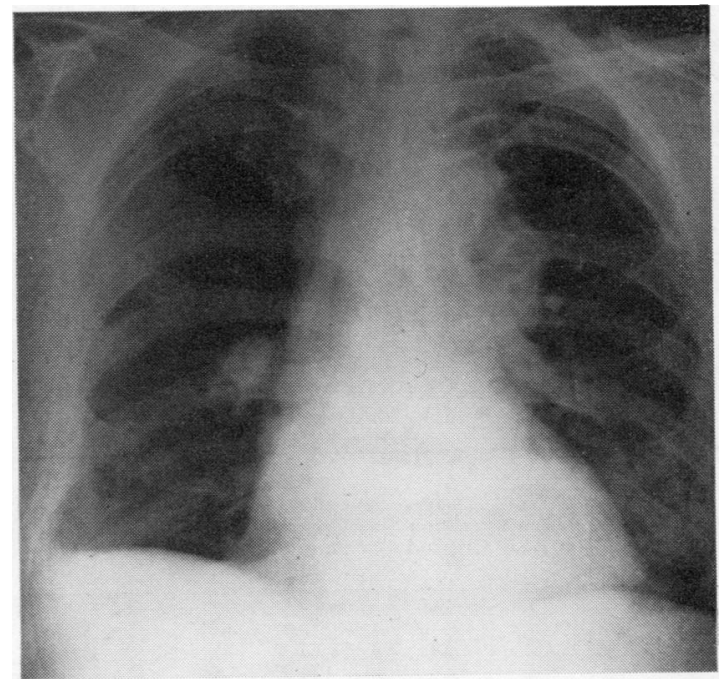

FIG. 5. (Patient 6, Table $I V, W . D$. in text.) Chest radiograph in 1969 showing third primary in the right lung. The left hilar shadow represents displacement of the aorta. (The 1956 and 1964 chest radiographs of this patient have been published previously.) 
graph in 1964, the patient was found to have developed a large circular opacity in the left lower lobe. The lesion was diagnosed as a second lung primary and had grown, judged by radiographic evidence, to a diameter of approximately 2 in. $(50 \mathrm{~mm}$.) in a space of four months. The patient was then aged 67 . A segmental resection of the apical segment of the left lower lobe was carried out with only a narrow margin of normal lung tissue around the resected tumour. In 1969 the patient was treated for anaemia. His chest radiograph (Fig. 5) showed a shadow in the right hilum which had been present, unchanged, for the preceding 18 months. Because it had been present for 18 months it was thought unlikely to be neoplastic. Three months after this radiograph was taken the patient complained of colicky abdominal pain. He was admitted to hospital. Laparotomy was carried out and a carcinoma of the descending colon was removed. The patient died some weeks following this operation from chest complications. Autopsy was carried out at the Birmingham General Hospital ; Dr. Hanarayan has supplied the findings. The carcinoma of the colon was a poorly differentiated adenocarcinoma involving all layers of the gut. Lymph nodes were not involved. All other organs were normal except for the lungs. Bilateral bronchopneumonia was present; in addition a tumour about 1 in. $(25.4 \mathrm{~mm}$.) in diameter was present in the right lower lobe; an adjacent lymph node was completely infiltrated by growth. This tumour was, after full consideration, designated an oat-cell primary lung tumour. The two previous primary lung tumours were basically squamous-cell and no trace existed at autopsy. They had been apparently cured by two operations, the latter of which was of the minimum permissible extent. In terms of patient resistance to tumour, the interest lies in the reasons for the simultaneous presence of a third and fourth primary tumour, each of which was surgically operable, after apparent cure of two previous primary tumours. The term 'cure' is used in the sense that no residual autopsy evidence of their presence existed. Histological examination of the entire tracheo-bronchial mucosa was not carried out.

The clinical course of this patient offers some scope for speculation on what resistance to tumour really means. It could on one hand be argued that a patient $\stackrel{\unrhd}{\varrho}$ who develops four primary tumours has no resistance, or, alternatively, because each one at the time of recognition was surgically operable, that high resis- $\overrightarrow{0}$ tance to general spread of each of the tumours $\vec{\perp}$ existed. If resistance implies an ability to confine a tumour locally to an organ for a considerable time. this patient's resistance was high. Simultaneously $\times$ recognizable, operable, multiple primary tumours in $N$ different organs are not common. The surgical and -1 autopsy findings at the time of this patient's death suggest that the presence of one of the tumours provided no immunity against the development of the $\mathrm{S}$ other.

Further case histories of some 24 second lung primaries detected need not be presented as evidence that patient resistance to tumour is incon- $-\vec{\theta}$ stant and variable at different periods throughout post-operative life. Considered in relation to the overall problem of lung carcinoma, 10-year post-o operative survivors showing evidence of fresh lung primaries are an almost insignificant percentage, but they represent a problem which requireso an explanation without appearing to generalizeo from the particular. They are a group of patients especially prone to develop carcinoma, as Watson (1965) points out, and if information on pre? clinical carcinoma is sought, it is from this group. that most information is likely to come because the carcinoma incidence will greatly exceed tha르 of the general population.

The statistical means of assessing variability of resistance is set out in Table $\mathrm{V}$. This table shoule be read independently of the other tables, and some explanation is required. It sets out details oR

TA B L E V

93 PATIENTS SURVIVING 3 YEARS, FROM 302 RESECTIONS MORE THAN 10 YEARS PREVIOUSLY, TO SHOW DEATH-RATE AND INCIDENCE OF DETECTION OF FRESH CARCINOMA WITHIN EACH PERIOD

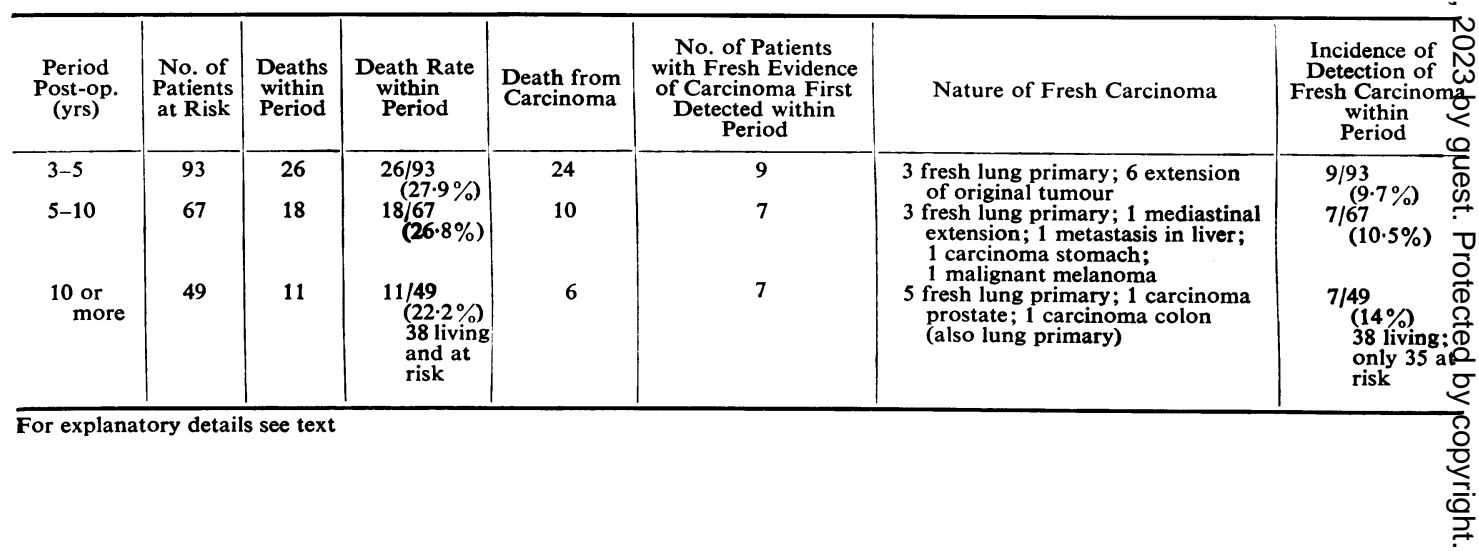


93 patients all operated on more than 10 years previously who were followed throughout, to show the absolute death rate during the different time periods. It reveals how 93 survivors at three years become 49 survivors at 10 years, with the proportion of deaths due to carcinoma. The reason for Table IIA showing 20 deaths from carcinoma between the fifth and tenth post-operative year, but Table $\mathrm{V}$ only 10 , is because some of the patients in Table IIA were operated upon less than 10 years previously. It can be seen in Table $\mathrm{V}$ that the absolute figure for deaths due to carcinoma in the 5-10 year period in this series was 10 out of $18(55.5 \%)$. Table $V$ also attempts to show a more disturbing figure, which is the number of patients in whom a diagnosis of fresh carcinoma was reached in each period. If the period 5-10 years is again considered, the figure was seven. The nature of the fresh carcinoma is stated in the adjacent column. Any patient entering the period with previously diagnosed carcinoma was excluded. The patient may be living or have died within the period, and if, for instance, the diagnosis of fresh carcinoma was made in the ninth year and the patient survived to the tenth year, he was not included in that period because the diagnosis was first made in the 5-10 year period. The time of diagnosis was synonymous with the time of the appearance of the fresh radiological abnormality. As these patients had frequent chest radiographs, the radiological change was likely to be an accurate indication of the period in which the carcinoma became clinically evident. Confirmation of this diagnosis by some ancillary method followed later. It is desirable that this table should not be misunderstood, because I consider it reveals that the longer the patient survives operation, the greater the chances of developing carcinoma. For instance, in the period after the tenth year with 35 patients still at risk, seven patients have a!ready had the diagnosis established later than the tenth post-operative year. The number of patients still at risk is 35 not 38 because, although still alive, three patients have carcinoma and are therefore no longer at risk of developing the disease. These figures suggest that the patient's resistance is variable and tends to diminish with age, if the rise in the detection rate of carcinoma is explicable by this theoretical concept. Comment must be limited on such a small series. None of these patients was exposed to known carcinogens to which they were not exposed before operation, and none has changed his environment. Second primary lung carcinoma has been diagnosed in both sexes and in all cell types of carcinoma except oat-cell, although the proportion of squamous-cell second tumours is markedly higher than the incidence of squamous-cell tumours at the original operation. The percentage of coal miners in the 10-year survivors is notably higher than the percentage at operation. There is evidence that increasing age is important but not vital. No evidence exists in our results that the tumour-patient relationship undergoes cyclical change for the reason that the second tumour may appear at any time; or in support of the supposition that carcinomatosis is the ultimate fate of those who survive a sufficiently long period after resection for the original carcinoma.

The smoking habits of patients with second primary lung tumours are being investigated. We have been impressed by the deterioration clearly visible in the general condition of the patient at the time the fresh radiological shadow appears. It has not always been clear whether the tumour extension caused the deterioration or the deterioration reduced resistance and allowed a microscopic tumour, previously held in check, to develop into radiologically visible carcinoma. Apart from experimental work, a great deal more clinical observation of the development of fresh carcinoma after operation is needed.

RESULTS OF OPERATION Three hundred and nineteen patients were explored more than 10 years ago, and the tumour was removed from 302 . Those surviving 10 years or more numbered 49 . Approximately one from every six patients resected survived 10 years, which is better than the anticipated figure. By comparing these figures with others, it was hoped to establish the advantages and benefits to the patient of maintaining a high resectability rate at operation.

Little is available for comparison. Table VI shows a comparison and a similar survival figure for different resectability rates. At first sight it might be claimed that a $16 \%$ survival from a $95 \%$ resectability rate were better figures from the point of view of patients salvaged by extended and non-curative operation than $16 \%$ survival

T A B L E V I

COMPARATIVE 10-YEAR SURVIVAL'FIGURES

\begin{tabular}{|c|c|c|c|}
\hline Author & Resections & $\begin{array}{c}\text { Resectability } \\
\text { Rate }(\%)\end{array}$ & $\begin{array}{l}\text { 10-year } \\
\text { Survivors }\end{array}$ \\
\hline $\begin{array}{l}\text { Thompson }(1960) \\
\text { Belcher and Anderson } \\
\begin{array}{lll}(1965) & \ldots & \ldots \\
\text { Present series } & \ldots & \ldots\end{array}\end{array}$ & $\begin{array}{l}120 \\
130^{1} \\
302\end{array}$ & $\begin{array}{l}77 \\
79 \\
95\end{array}$ & $\begin{array}{l}20(16.6 \%) \\
21(16.1 \%) \\
49(16.2 \%)\end{array}$ \\
\hline
\end{tabular}

1 Hospital deaths excluded 
from a $77 \%$ resectability. This claim cannot be maintained on these figures. There is no assurance, for instance, that the extent of the tumour was comparable in each series; the different hospital death rates must be considered, potential survivors may have died from treatable conditions, and it could be maintained from the Table VI figures, taken in isolation, that all the patients represented by the different resectability rates all died, and that it was a similar $16 \%$ from each series who survived, namely, those submitted to curative resection. That this is not so in our series can be deduced from the survivors from noncurative and extended operation shown in Tables III and IV. Considering these two tab'es with the results in Table VI, the policy of removing the tumour whenever possible, even though partial resection only is accomplished on occasions, is supported, provided the operative mortality rate is not excessive and that patients are not made worse by applying this principle. Since the early results were first reported (Abbey Smith, 1957), we can find no reason, from close observation of the results in each post-operative time period, for altering our view that the tumour must be removed if the patient is to survive, and that a high resectability rate can be achieved with an acceptable operative mortality. Discussing the therapeutic implications of the biological aspects of cancer, Woodruff (1969) reported 'the failure to achieve total ablation of a tumour does not necessarily preclude the possibility of complete cure'. Applying this statement to lung cancer, our results endorse this doctrine, although at times it is difficult to understand the fundamental reason for the patient's survival, or for the apparent total regression of residual cancer in at least three patients in the series. Because this phenomenon followed operation, the term spontaneous regression is inadvisable, for, by using this term, factors which tend to enhance or catalyse the patient's natural resistance may remain concealed, simply by ex- $\frac{\stackrel{\vec{F}}{+}}{9}$ plaining the occurrence as a spontaneous event. A number of the 10-year patients would be re- $\frac{0}{\omega}$. garded as unlikely 10 -year survivors at the time $\overrightarrow{\widetilde{D}}$ of the original operation, two after non-curative $\varrho$ resections, four with oat-cell tumours, nine with hilar node involvement, and a number following $\vec{\circ}$ extended operation. The factors which enable the patient to survive to 10 years are complex and ill $\vec{\omega}$ understood. The last word as far as our philo- $\stackrel{?}{\rightarrow}$ sophy is concerned can be left with Price Thomas $\vec{x}$ (1959), who stated 'there is every justification for N extending our indications for surgery to include-such extensions of the disease that are within the competence of removal, for none can judge at theo time of operation which patient will or will not have a long-term survival apparently free fromc disease'.

\section{REFERENCES}

Abbey Smith, R. (1957). The results of raising the resectability rate in operations for lung carcinoma. Thorax, 12, 79

Belcher, J. R., and Anderson, R. (1965). Surgical treatment of carcinoma of the bronchus. Brit. med. J., 1, 948.

Bell, J. W. (1967). Abdominal metastasis and cancer of the lung. Ann. thorac. Surg., 4, 598.

Chamberlain, J. M., McNeill, T. M., Parnassa, P., and Edsall, J. R. $\overline{\bar{O}}$ (1959). Bronchogenic carcinoma. An aggressive surgicalo attitude. J. thorac. cardiovasc. Surg., 38, 727.

Feinmann, L. (1960). Long-term functional results after pneumonectomy. Part of Thoracic Society Symposium: "The present position relating to cancer of the lung'. Thorax, 15, 19.

Higgins. G. A., Lawton, R., Heilbrunn, A., and Keehn, R. J. (1969). 곡 Prognostic factors in lung cancer. Ann. thorac. Surg., 7, 472

Le Roux, B. T. (1968). Bronchial Carcinoma. Livingstone, Edinburgh. Nohl, H. C. (1960). A three year follow-up of classified cases of bronchogenic carcinoma after resection. Part of Thoracic Society Symposium. 'The present position relating to cancer of the lung'. Thorax, 15, 11.

Ogilvie, C., Harris, L. H., Meecham, J., and Ryder, G. (1963). Ten years after pneumonectomy for cancer. Brit. med. J., 1, 1111.

Price Thomas, Sir Clement (1959). Conservative and extensive resection for carcinoma of the lung. Ann. roy. Coll Surg. 3 Engl., 24, 345.

Thompson, V. C. (1960). Results of resection. Part of Thoracic? Society Symposium: "The present position relating to cancer of the lung'. Thorax, 15, 5 .

Watson, W. L. (1965). Ten-year survival in lung cancer. A study ofo 56 cases. Cancer (Philad.), 18, 133.

Woodruff, Sir Michael (1969). The challenge of osteosarcoma. D Ann. roy. Coll. Surg. Engl., 44, 299. 